\title{
Long-term effects of organic amendments on the recovery of plant and soil microbial communities following disturbance in the Canadian boreal forest
}

\author{
Aria S. Hahn • Sylvie A. Quideau
}

Received: 1 February 2012 / Accepted: 21 May 2012 /Published online: 19 June 2012

(C) The Author(s) 2012. This article is published with open access at Springerlink.com

\begin{abstract}
Background and Aims Ecosystem recovery following disturbance requires the reestablishment of key soil biogeochemical processes. This long-term 7 year study describes effects of organic material, moisture, and vegetation on soil microbial community development in the Athabasca Oil Sands Region of Western Canada.

Methods Phospholipid fatty acid analysis was used to characterize and compare soil microbial community composition and development on reclaimed and natural forest sites. Additionally, we conducted a laboratory moisture manipulation experiment.

Results The use of forest floor material as an organic amendment resulted in a greater percent cover of upland vegetation and placed the soil microbial community on a faster trajectory towards ecosystem recovery than did the use of a peat amendment. The soil microbial composition within the reclaimed sites exhibited a greater response to changes in moisture than did the soil microbial communities from natural sites.

Conclusion Our research shows that the use of native organic amendment (forest floor) on reclaimed sites, and the associated establishment of native vegetation
\end{abstract}

Responsible Editor: Timothy Cavagnaro.

A. S. Hahn $(\bowtie) \cdot$ S. A. Quideau

Department of Renewable Resources, University of Alberta,

3-40C Earth Sciences Building,

Edmonton, Alberta, Canada T6G 2E3

e-mail: ahahn@ualberta.ca promote the development of soil microbial communities more similar to those found on natural forest sites. Additionally, soil microbial communities from natural sites may be more resistant to changes in soil moisture than those found on reclaimed sites.

Keywords Phospholipid fatty acid (PLFA) analysis . Native revegetation - Moisture regimes · Soil microbial communities $\cdot$ Boreal mixed-wood forest $\cdot$ Athabasca Oil Sands Region

\section{Introduction}

In natural areas, forest floor layers overlying mineral soils contribute to ecosystem recovery after disturbance as they are rich sources of native plant seeds and propagules (Pare et al. 1993; Whittle et al. 1997), and provide energy and nutrients to the soil microbial community (Fyles and McGill 1987; Vancleve et al. 1993). Biogeochemical cycling between soils, microbes, and plants is one of the most critical factors required to insure long-term sustainability in forest ecosystems. While the soil microbial community is responsible for processes such as nutrient cycling (Wagner 1998) and organic matter accumulation (Bradshaw 1984; Frouz et al. 2007), which are central to the support of plant growth (Wagner 1998), soil microbial communities have also been found to be highly influenced by vegetation (Bach et al. 2008). For example, in the boreal mixed-wood forest of 
western Canada, aspen (Populus tremuloides Michx.) dominated stands host soil microbial communities that have greater total biomass and are structurally different from the communities found under spruce (Picea glauca (Moench) Voss) dominated stands (Flanagan and Vancleve 1983; Hannam et al. 2007; Lindo and Visser 2003). Further, plant communities determine litter composition (Saetre and Baath 2000), a primary source of energy and nutrients for the soil microbial community (Schutter and Dick 2001; Broughton and Gross 2000).

Abiotic conditions such as soil $\mathrm{pH}$ (Priha et al. 2001), temperature and moisture may play an equally important role as vegetation in driving soil microbial community composition (Fierer et al. 2003; Zak et al. 1999; Zogg et al. 1997). To illustrate, patterns in soil microbial community composition were so affected by seasonal precipitation that the influence of vegetation was masked during times of high precipitation, but perceivable during low rainfall seasons (Swallow et al. 2009). Similarly, microbial biomass was shown to increase in the spring and decrease in the autumn when environmental conditions are drier in temperate grasslands (Bardgett et al. 1999). Climatic differences and specifically soil moisture regimes have been proposed as important drivers of soil microbial community composition in cases of significant temporal seasonal differences (Bardgett et al. 1999; Bell et al. 2009; Prevost-Boure et al. 2011; Swallow et al. 2009). While many studies have investigated seasonal effects on the soil microbial community, to our knowledge no study characterizing composition of the soil microbial community has spanned more than three years (e.g.; Bell et al. 2008; Bell et al. 2009), and captured the entirety of site climatic conditions.

Soil microbial communities, are thus controlled by an intricate and dynamic combination of biotic and abiotic conditions. A better understanding of the drivers of soil microbial community composition will further current knowledge in ecosystem processes and lead to improved sustainable management of natural resources. The overall objective of this study was to determine the long-term influence of two types of organic amendments on soil microbial community development following open-pit mining in the Athabasca oilsands region of northwestern Alberta, Canada. Currently two sources of amendments are used in the region: peat, which is salvaged from the abundant lowland pre-mining areas, and forest floor, which is obtained from upland boreal forest stands similar to the reclamation target ecosystems. The application of forest floor materials to reclaimed areas has been shown to provide a source of propagules, and results in a greater native revegetation response compared to sites reclaimed with peat (Mackenzie and Naeth 2006). However, whether the greater presence of native plants promotes soil microbial communities more similar to those on natural forest sites is yet unknown. We hypothesized that the combined effect of upland forest floor organic matter and associated native vegetation would promote soil microbial communities more similar to those found in natural forest stands as compared to soils reconstructed using lowland organic matter. We characterized the soil microbial community from field samples collected over seven consecutive years. Additionally, we assessed the relative importance of abiotic conditions on the soil microbial communities of both reclaimed and natural forested sites, by manipulating soil moisture in a laboratory incubation experiment. Here, we hypothesized that by increasing moisture, and thus lifting soil moisture limitation, the soil microbial communities on the reclaimed sites, typically found to have significantly less soil moisture that the natural sites (McMillan 2007), would become more similar to those found on the natural reference stands.

\section{Materials and methods}

\section{Study area}

The research sites were located approximately $40 \mathrm{~km}$ north of Fort McMurray, Alberta $\left(56.72^{\circ} \mathrm{N} 111.37^{\circ} \mathrm{W}\right)$ in the Central Mixedwood Region of the Canadian boreal forest (Natural Regions Committee 2006), within the Athabasca Oil Sands Region (AOSR). Glaciolacustrine sediments and morainal till make up $45 \%$ of the soil parent materials in the area, while an additional $15 \%$ of the landscape is covered by colluvial and glaciofluvial deposits. Medium to fine textured Gray Luvisols (Haplocryalfs according to the USDA classification) are the most prevalent mineral soils, although Dystric Brunisols (Dystrocryepts) and Gleysols (Cryaquepts) are found on approximately $10 \%$ and $5 \%$ of the region, respectively. The remaining $40 \%$ is occupied by organic soils, which occur within bogs and treed fens (Natural Regions Committee 
2006; Soil Classification Working Group 1998). Trembling aspen (Populus tremuloides Michx.), white spruce (Picea glauca (Moench) Voss), and jack pine (Pinus banksiana Lamb.) dominate the forest landscape on the gently undulating plains. The region receives an average of $456 \mathrm{~mm}$ of precipitation annually (Table 1), and has an average of 69 frost-free days (Environment Canada 2010). Summers are short and cool with an average temperature of $16.3{ }^{\circ} \mathrm{C}$ while the long winters that can extend from September to May experience an average temperature of $-21.5{ }^{\circ} \mathrm{C}$ (Turchenek and Lindsay 1982).

Resource extraction in the Athabasca Oil Sands Region (AOSR) disturbs ecosystems at the landscape scale. Two of largest oil sands mining companies in the AOSR, Syncrude Canada Ltd and Suncor Energy Inc., use trucks and shovels to remove $40 \mathrm{~m}$ of geological material and then carry the bitumen-rich sands to the appropriate extraction facilities. Prior to the onset of mining, surface materials $(0-3 \mathrm{~m})$ are removed in lifts and stored separately from the deeper geological material, called overburden, until they can be used to reconstruct soils (Lanoue 2003). During reclamation, soil-like profiles are created by placing organic amendments atop mineral materials, including overburden or tailings sand (a byproduct of the bitumen refining process). Currently, the two main types of organic amendments used in upland reclamation in the AOSR consist of either peat or forest floor material obtained by salvaging peat (up to meters deep) or forest floor (several centimeters deep) from either adjacent peatlands or upland forests. Peat may be used directly, or organic reclamation treatments may be obtained by mixing either peat or forest floor materials with the mineral soil below (Fung and Mackyk 2000), resulting in either a peat-mineral soil mix (PM), or a forest floor-mineral soil mix (FFM). These treatments typically range in organic: mineral material ratios between approximately $40 \%$ and $70 \%$ (Lanoue 2003) and thus differ in both organic carbon content $\left(\mathrm{g} \mathrm{Kg}^{-1}\right.$ ) and C:N ratio (Table 2).

Three sites were used in this study. Each of these three sites contained at least one plot reclaimed with FFM and one reclaimed with PM. The PM and FFM reclamation treatments for all sites were harvested from peatlands and aspen-dominated upland forests located in the Athabasca River valley and placed at a depth of 5-20 cm on the reclaimed plots. Sites were constructed from 1998 to 2004, and were located on either Syncrude Canada Ltd. mine site, or Suncor Energy Inc. reclamation area (Table 3). Planting and fertilization varied among sites. As described by McMillan (2007), vegetation on the reclaimed sites was dominated by common yarrow (Achillea millefolium L.), fireweed (Epilobium angustifolium L.), and graceful cinquefoil (Potentilla gracilis Dougl Ex Hook var. gracilis), peavine sp. (Lathyrus sp.), sweet clover sp. (Melilotus sp.) and wild strawberry (Fragaria virginiana Mill.).

Luvisolic soils (Haplocryalfs) supported the three mature forest (all $>70$ years of age) reference stands included in this study. The reference sites included two aspen-dominated sites, as well as a mixed white spruce-aspen stand, which were located either on the Syncrude Canada Ltd. mine site, or in close proximity (Table 3). The two natural aspen-dominated stands supported understory vegetation typical of this type of ecosystem, that includes low bush cranberry (Viburnum edule Michx.), rose (Rosa sp.), green alder (Alnus crispa (Ait.) Pursh), Canada buffaloberry (Shepherdia canadensis (L.)), hairy wild rye (Elymus innovatus, (Beal) Pilg), bunchberry (Cornus canadensis, L.), wild sarsaparilla (Aralia nudicaulis L., Araliaceae), dewberry (Rubus pubescens, Raf.) and fireweed (Epilobium angustifolium L.). Understory vegetation at the mixed white spruce-aspen stand was similar to that

Table 1 Total annual and August precipitation, and mean August temperature in Fort McMurray, AB, Canada, from 2004 to 2010 , and 30 year normal (Environment Canada 2010)

\begin{tabular}{llllllll}
\hline & \multicolumn{1}{l}{ Year } & & & & \\
\cline { 2 - 8 } & 2004 & 2005 & 2006 & 2007 & 2008 & 2010 & $1971-2000$ \\
\hline Total annual precipitation (mm) & 327 & 376 & 362 & 267 & 422 & 328 & 456 \\
Annual August precipitation $(\mathrm{mm})$ & 17 & 65 & 37 & 70 & 155 & 76 & 73 \\
Mean August temperature $\left({ }^{\circ} \mathrm{C}\right)$ & 12.7 & 14.1 & 15.5 & 12.9 & 16.4 & 15.4 & 15.3 \\
\hline
\end{tabular}


Table 2 Selected topsoil properties $(0-7.5 \mathrm{~cm}$ or as indicated) at the natural and reclaimed sites (FFM: plots reclaimed with forest floor-mineral soil mix; PM: plots reclaimed with peat-

\begin{tabular}{|c|c|c|c|c|c|c|}
\hline Site & Treatment & Texture ${ }^{a}$ & $\begin{array}{l}\mathrm{OC} \\
\left(\mathrm{g} \mathrm{Kg}^{-1}\right)\end{array}$ & $\mathrm{C} / \mathrm{N}$ & $\mathrm{PW}^{\mathrm{d}}(\%)$ & $\mathrm{pH}^{\mathrm{a}}$ \\
\hline \multirow[t]{2}{*}{ Site 1} & FFM & loam & $50^{b}$ & $21.3^{b}$ & 14 & 5.3 \\
\hline & PM & loam & $100^{b}$ & $21.5^{b}$ & 17 & 5.9 \\
\hline \multirow[t]{2}{*}{ Site 2} & FFM & loamy sand & $40^{b}$ & $48.0^{\mathrm{b}}$ & 8 & 5.0 \\
\hline & $\mathrm{PM}$ & sandy loam & $80^{\mathrm{b}}$ & $29.1^{b}$ & 8 & 6.0 \\
\hline \multirow[t]{2}{*}{ Site 3} & FFM & clay loam & $40^{c}$ & $22.9^{\mathrm{c}}$ & 10 & 5.4 \\
\hline & $\mathrm{PM}$ & clay loam & $80^{\mathrm{c}}$ & $31.9^{\mathrm{c}}$ & 13 & 6.2 \\
\hline Natural Forest Stand & - & - & $165^{\mathrm{b}}$ & $18.3^{\mathrm{b}}$ & 60 & 4.7 \\
\hline
\end{tabular}

a sampled September 2010

b McMillan 2005 sampled to a depth of $7 \mathrm{~cm}$

c Mackenzie 2006 sampled to a depth of $10 \mathrm{~cm}$

d sampled September 2009

of the aspen-dominated sites with the addition of stairstep moss (Hylocomium splendens (Hedw.)), Scheber's moss (Pleurozium schreberi (Michx.)) and knight's plume moss (Ptilium crista-castrensis (Hedw)).

Field assessment and soil sampling

\section{Vegetation assessment}

In August 2010, five $5 \mathrm{~m}^{2}$ locations were selected for further vegetation characterization at $5 \mathrm{~m}$ intervals along a $25 \mathrm{~m}$ transect on both reclamation treatments at all reclaimed sites, as well as at the two natural sites located on the Syncrude Canada Ltd. mine site. Within each $5 \mathrm{~m}^{2}$ location, percent cover of graminoids, forbs, shrubs, trees, bare ground, litter and moss were recorded (AMEC Earth and Environmental 2003; AMEC Earth and Environmental 2006). Each class was assessed on a $0-100 \%$ basis. Average number of trees present in the reclaimed plots (including Site 3 , where volunteer trees were present) was also recorded.

\section{Soil sampling}

Soil samples $(0-7.5 \mathrm{~cm})$ from the reclaimed sites were taken annually from 2004 to 2010 for microbial characterization (Table 3). Annual sampling always occurred in August for consistency reasons. However, mineral soil mix) in the Athabasca Oil Sands Region (OC: organic carbon; Pw: gravimetric water content) 
sieved to $4 \mathrm{~mm}$ prior to the moisture manipulation experiment.

Laboratory Analyses

Soil physical and chemical properties

Gravimetric water content was calculated on a dryweight basis by oven drying soils at $65^{\circ} \mathrm{C}$ for 3 days (ISO 11465 1993). To measure $\mathrm{pH}, 0.01 M$ calcium chloride was added to oven-dried soil (not sieved) using a 2:1 solution:soil dilution ratio as described in (Kalra and Maynard 1991). Texture was determined on oven-dried, sieved $(<2 \mathrm{~mm})$ soils, using the hydrometer method as outlined in (Sheldric and Wang 1993). Total carbon and nitrogen contents in ball ground (Retsch, MM200) samples were measured using a Costech 4010 Elemental Analyzer System (Costech Analytical Technologies Inc., Valencia, CA, USA) fitted with a thermal conductivity detector.

\section{Moisture manipulation incubation experiment}

Four moisture levels were selected for this experiment, $60 \%$ (a water content similar to that measured in the natural stands), $45 \%, 30 \%$ and $15 \%$ (a water content similar to that measured in the reconstructed soils) (Table 2) all of which were calculated on a dryweight gravimetric basis. Three replicates from the natural site and each treatment from all three reclaimed sites were prepared for the four moisture levels selected using deionized water (for a total of 84 samples). The samples were incubated in sterile Whirlpack ${ }^{\mathrm{TM}}$ bags for 6 months in a dark room kept at $22^{\circ} \mathrm{C}$. Bags were opened weekly to avoid samples becoming anaerobic. They were weighed monthly and the moisture level was readjusted to its original moisture content by adding deionized water as needed.

Phospholipid fatty acid (PLFA) analysis was used to characterize the soil microbial community composition for three separate data sets (total of 420 samples): 1. a 7 year chronosequence in which samples collected in August from 2004 to 2010 were included; 2. a comparison of seasonal versus annual differences; and 3 . the moisture manipulation experiment. Samples were taken from the deep freeze, and freeze dried, prior to PLFA analysis to remove moisture and maintain the integrity of the PLFAs. Polar lipids were extracted from the soil samples $(1.5 \mathrm{~g})$ through a modified Bligh and Dyer 
extraction (Frostegard and Baath 1996; Frostegard 1996). Extracts were then isolated using pre-packed silicic acid columns (Agilent Technologies, Wilmington, DE). Lastly, a mild alkaline methanolysis was used to form fatty acid methyl esters (PLFAs), which were then separated and quantified with an Agilent 6890 Series capillary gas chromatograph (Agilent Technologies, Wilmington, DE) fitted with a $25 \mathrm{~m}$ Ultra $2(5 \%$ phenyl)-methylpolysiloxane column. Peaks were identified using the MIDI peak identification software (MIDI, Inc., Newark, DE) and a bacterial fatty acid standard (Hannam et al. 2006; Swallow et al. 2009). PLFA data were expressed on a nmol PLFA $\mathrm{g}^{-1}$ basis after being relativized by the internal standard.

\section{Statistical analyses}

All PLFAs ( $\leq 20$ carbons in length) identified by the MIDI software were included in the analysis. Total microbial biomass was calculated by summing all PLFAs on a nmol PLFA $\mathrm{g}^{-1}$ basis. A Hellinger transformation was used to relativize the data (Legendre and Gallagher 2001). Non-metric multi-dimensional scaling (NMDS) ordinations were used to explore the PLFAs data in the long-term community composition study and the moisture manipulation experiment using PC-Ord software version 5 (MjM Software Design, Gleneden Beach, OR). Variation in the soil microbial community by year and season, both within and between sites was assessed. The NMDS ordinations were also used to compare seasonal versus annual differences. This method was selected given its suitability for multivariate data ( $~ 80$ plfas were measured per sample). Further, this method is well adapted to the large range in data distribution and variance that we observed between samples, years, months, sites and reclamation treatments. The Multi-Response Permutation Procedure (MRPP) was used to test for significant differences among microbial grouping patterns linked to specific groups (such as treatment, site, year or moisture level) as identified on the NMDS ordinations. Results from an MRPP analysis include the following three variables: the $\mathrm{T}$ value, which represents the difference(s) between groups, a more negative value signifying a greater difference; the A value, which represents the variation within groups, where 1 signifies that all points within the group are identical and 0 indicates a variation equal to that of random numbers; and the $\mathrm{p}$ value, which represents the significance of these values (Zimmerman et al. 1985). The Sorensen (Bray-Curtis) dissimilarity index was used for all ordinations and MRPPs. An alpha of 0.05 was used for all statistical tests.

The R package (version 2.12.1, R Development Core Team) was used to test assumptions and conduct Wilcoxon rank sum tests comparing the total microbial biomass between treatments and among years, sites and moisture levels. A Bonferroni adjustment was used for multiple comparisons to maintain the family-wise Type I error rate at 0.05 . Data collected from the vegetation assessment were used to calculate arithmetic means and standard deviations; however, no further statistical tests were conducted on the vegetation data.

\section{Results}

Plant and soil characteristics

The natural sites possessed, on average, over double the vegetative cover $(226 \%)$ and number of trees per plot (2.7) of any given reclaimed site (Fig. 1). Differences between the two reclamation treatments (forest floor versus peat amendments) were visually apparent at each site in terms of vegetative cover and plant functional group distribution. Higher percent cover of trees, shrubs and forbs was found on plots reclaimed with the forest floor material (FFM) when compared to those reclaimed with the peat (PM). Additionally, higher numbers of trees per plot and total vegetative cover were observed on all plots reclaimed with FFM (1.5 and $138 \%$, respectively) compared to those reclaimed with PM (0.2 and $87 \%$, respectively). Plots reclaimed with FFM thus appeared more similar to the natural sites than those reclaimed with PM in terms of total plant cover and number of trees for all three reclaimed sites. Additionally, the percent cover of both forbs and shrubs found on the natural sites was more similar to plots reclaimed with FFM than to plots reclaimed with PM.

While all topsoil properties lacked sufficient replication to perform statistical analyses, trends in the data can be drawn based on descriptive statistics. Within a given site, soil texture was similar between reclamation treatments (Table 2). All soils had a comparable loamy texture, Site 2 contained the highest sand 


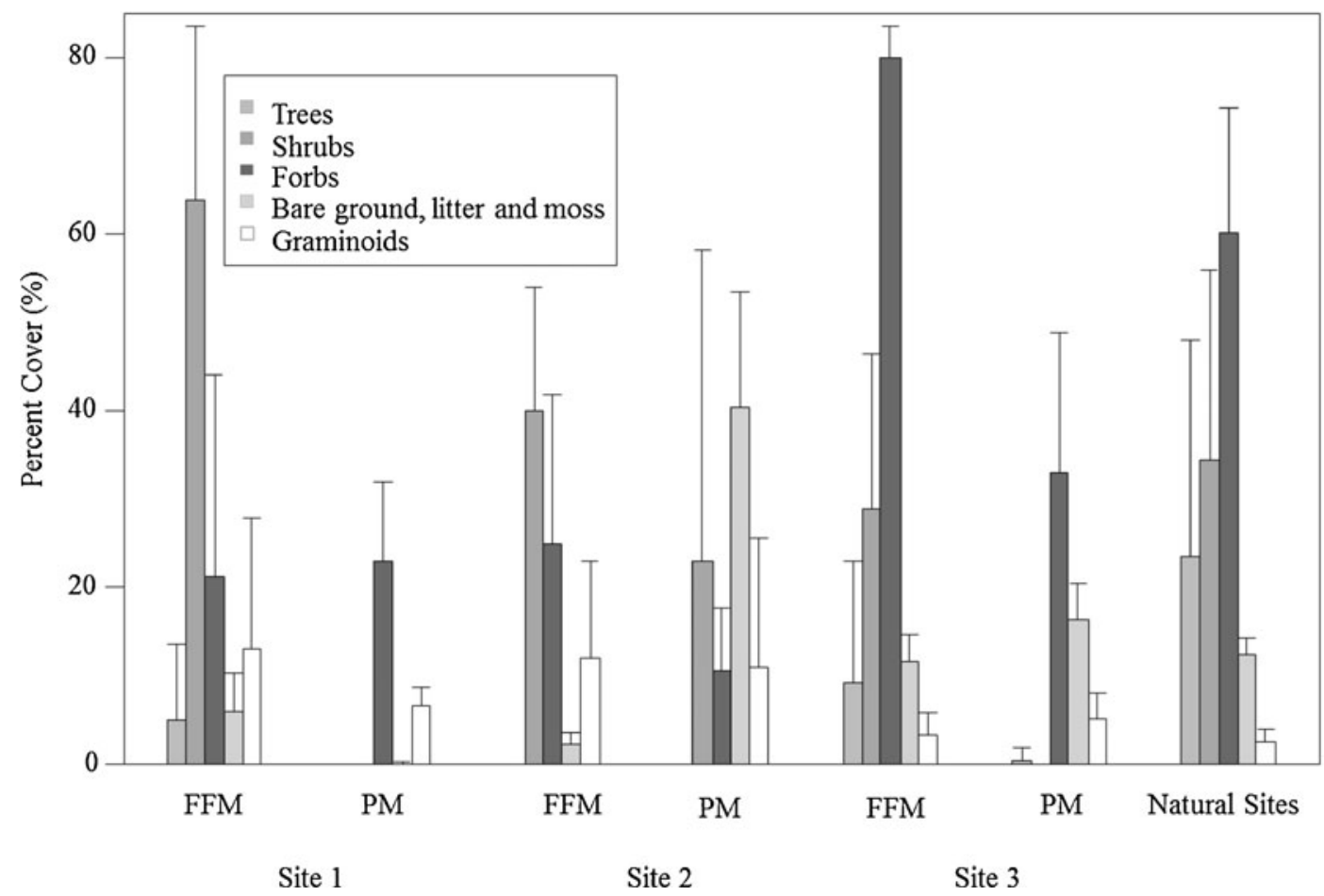

Fig. 1 Percent cover of bare ground trees, shrubs, forbs and graminoids growing on natural forest sites and plots reclaimed with FFM (forest floor-mineral soil mix) and PM (peat-mineral soil mix) in the Athabasca Oil Sands Region

percentage, and Site 3 contained the most clay. Soils from the natural sites and the FFH reclaimed plots had comparable $\mathrm{pH}$ values (Table 2). The $\mathrm{pH}$ of soils from plots reclaimed with PM was higher by an average of $0.7 \mathrm{pH}$ units when compared to the plots reclaimed with FFM and the natural control site. The natural stands contained five to six times the soil gravimetric water content of any of the reclaimed sites. On the reclaimed sites, soil water content varied among sites rather than between reclamation treatments. The natural reference stands also contained approximately double the organic carbon of any of the reclaimed sites. Additionally, while the carbon to nitrogen ratios did not show any consistent differences between organic amendment types on the three reclaimed sites, the soil organic carbon content of the PM plots contained approximately double that of the FFM plots.

Long term microbial community composition monitoring

Wilcoxon rank sum tests failed to detect any significant differences in total microbial biomass between plots reclaimed with FFM and plots reclaimed with
PM within any of the reclaimed sites, for any given year. Consequently, total soil microbial biomass data from both organic amendment treatments on each site were compiled to assess the relationship between biomass and time since initiation of reclamation. Soil microbial biomass was found to increase with time since reclamation on all reclaimed sites and ranged from 75 (2004) to 354 (2010) nmol PLFA $\mathrm{g}^{-1}$ (Fig. 3). However, within the reclaimed plots, microbial biomass remained at least $50 \%$ below the values that were measured in 2004, 2009 and 2010 at the natural sites, i.e. 576 (2004), 987 (2009), and $623 \mathrm{nmol}$ PLFA g ${ }^{-1}$ (2010). An NMDS ordination of the soil microbial community composition as measured annually on all reclaimed sites from 2004 to 2010 produced a three dimensional solution, which explained $40.1 \%$, $21.1 \%$ and $29.9 \%$ of the variation on the axes respectively (Fig. 2). A stress of 13.9 was reached after 115 iterations. Year was found to be a stronger grouping factor $(T=-60.42)$ than organic amendment type $(T=-13.69)$ or site $(T=-23.37)$. A secondary matrix including climatic data (Table 1) did not reveal any significant correlations that could help explain the annual differences in soil microbial communities. The 
Fig. 2 NMDS ordination of topsoil PLFA profiles sampled annually in August

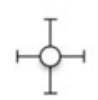

(2004-2010) on three

reclaimed sites in the

Athabasca Oil Sands Region

averaged by treatment, site and year. Error bars denote one standard error from the mean for the $\mathrm{x}$ and $\mathrm{y}$ co-ordinates. The $\mathrm{T}$ value represents the difference(s) between groups, a more negative value signifying a greater difference; the A value represents the variation within groups, where 1 signifies that all points within the group are identical and 0 indicates a variation equal to that of random numbers; and the $p$ value represents the significance of these values (Zimmerman et al. 1985)

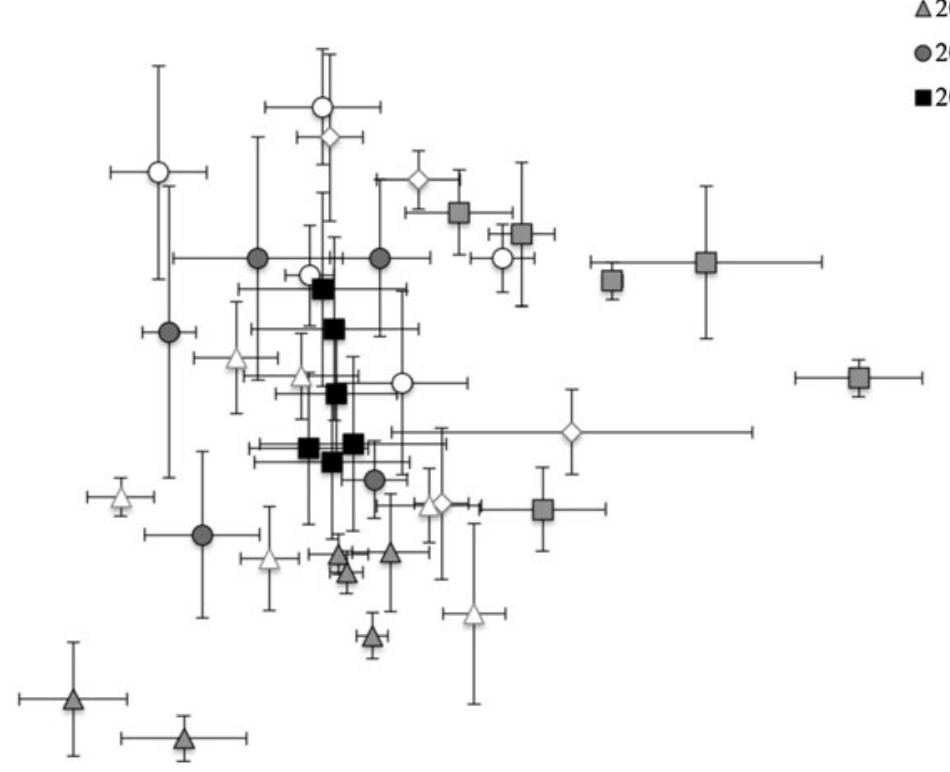

effect of season versus year of sampling was also investigated (data not shown). Specifically, an NMDS ordination of the soil microbial communities sampled at the reclaimed sites in August as well as May 2005, and May and September of 2010 generated a two dimension solution which explained $57.2 \%$ and $32.0 \%$ of the variation on the axes respectively, with a final stress of 16.9 after 234 iterations. The MRPP analysis identified year (T: -45.98 ; A: 0.01$)$ to be a stronger grouping factor than season (T: -19.07 ; A: $0.02)$.

The NMDS analysis of the complete 2004-2010 soil microbial community chronosequence (Fig. 2) further showed that all years were significantly different from one another $(p<0.05)$. Years chronologically closer were not found to be more similar to one another in all cases. For instance, 2004 was most similar to 2009 (T: -14.90; A: 0.07), and 2007 was most similar to 2004 (T: -24.29; A: 0.11), although 2005 was most similar to 2004 (T: -15.32 ; A: 0.08$)$; and 2010 was most similar to 2009 (T: -5.63; A: 0.03). Consequently, time since reclamation was not the sole primary driver of soil microbial composition at these reclaimed sites. Additionally, using climatic data (Table 1) as vectors in the NMDS, no significant relationship was identified between the pattern of years found in the NMDS analysis and any of the climatic variables tested (vectors did not appear at a significance level below 0.05).

Several additional MRPP analyses were used to specifically assess the influence of site and reclamation treatment on soil microbial community composition within each individual year (Table 4). Significant differences among reclamation sites and between organic amendment treatments were found every year (with the exception of treatment in 2005). From 2004 to 2007 , site was found to be a stronger grouping factor than reclamation treatment. However, in later years (2008-2010), reclamation treatment became a stronger grouping factor and surpassed that of site in 2008 and 2010 (e.g.; in 2008, site $T=-7.11$ vs. reclamation treatment: $\mathrm{T}:-8.46)$. This suggests that while site was initially the most important driver, the influence of organic amendment type on soil microbial composition increased with time since reclamation.

The soil microbial community composition of the reconstructed soils remained statistically different $(p \leq$ 0.001 ) from that of the reference forest stands in all 3 years in which the natural soil microbial community was assessed; i.e. in 2004, 2009 and 2010 (Table 5). Indicator species analysis (performed in PC-Ord) did 
Table 4 Multi-response permutation procedure (MRPP) results for soil microbial community composition (PLFA) in the Athabasca Oil Sands Region. Treatment compares FFM (plots reclaimed with forest floor-mineral soil mix) to PM (plots reclaimed with peat-mineral soil mix). Site compares three reclaimed sites (Site 1, Site 2 and Site 3 ) to one another. The T value represents the difference(s) between groups, a more negative value signifying a greater difference; the A value represents the variation within groups, where 1 signifies that all points within the group are identical and 0 indicates a variation equal to that of random numbers; and the $\mathrm{p}$ value represents the significance of these values (Zimmerman et al. 1985)

\begin{tabular}{|c|c|c|c|c|c|c|}
\hline \multirow[t]{2}{*}{ Year } & \multicolumn{3}{|c|}{ Treatment } & \multicolumn{3}{|l|}{ Site } \\
\hline & $\mathrm{T}$ & A & $p$ & $\mathrm{~T}$ & A & $p$ \\
\hline 2004 & -4.19 & 0.04 & 0.002 & -20.53 & 0.22 & $<0.001$ \\
\hline 2005 & -1.66 & 0.022 & 0.069 & -5.03 & 0.10 & 0.001 \\
\hline 2006 & -3.50 & 0.039 & 0.007 & -7.62 & 0.12 & $<0.001$ \\
\hline 2007 & -1.94 & 0.020 & 0.044 & -2.23 & 0.02 & 0.020 \\
\hline 2008 & -8.46 & 0.087 & $<0.001$ & -7.11 & 0.11 & $<0.001$ \\
\hline 2009 & -7.08 & 0.096 & $<0.001$ & -7.58 & 0.12 & $<0.001$ \\
\hline 2010 & -9.68 & 0.095 & $<0.001$ & -7.77 & 0.11 & $<0.001$ \\
\hline
\end{tabular}

not reveal any identifiable PLFA that could help explain the differences between communities. However, the separation between both reclamation treatments and the natural reference sites decreased with time, as can be seen from the increasingly less negative $T$ values in the MRPP analyses. These decreased from 11.42 for FFM and -11.54 for PM in 2004 to -6.28 for FFM and -10.33 for PM in 2010. Furthermore, the soil microbial community associated with the FFM treatments appeared to be converging towards the natural soil microbial community more quickly, as

Table 5 Multi-response permutation procedure (MRPP) results for soil microbial community composition (PLFA) in the Athabasca Oil Sands Region comparing samples collected from plots reclaimed with FFM (forest floor-mineral soil mix) and PM (peat-mineral soil mix) to those collected from natural forest sites (Natural). The $\mathrm{T}$ value represents the difference(s) between groups, a more negative value signifying a greater difference; the A value represents the variation within groups, where 1 signifies that all points within the group are identical and 0 indicates a variation equal to that of random numbers; and the $\mathrm{p}$ value represents the significance of these values (Zimmerman et al. 1985)

\begin{tabular}{llrlr}
\hline Year & Comparison & T & A & $p$ \\
\hline 2004 & FFM vs. Natural & -11.42 & 0.18 & $<0.001$ \\
& PM vs. Natural & -11.54 & 0.16 & $<0.001$ \\
2009 & FFM vs. Natural & -4.10 & 0.07 & 0.001 \\
& PM vs. Natural & -6.70 & 0.10 & 0.001 \\
2010 & FFM vs. Natural & -6.28 & 0.08 & 0.001 \\
& PM vs. Natural & -10.33 & 0.17 & 0.001 \\
\hline
\end{tabular}

a greater increase in the $\mathrm{T}$ values was found in plots associated with FFM compared to plots associated with PM.

Moisture manipulation experiment

The NMDS ordination of the soil microbial communities at all four moisture levels produced a threedimensional solution, explaining $14.6 \%, 52.5 \%$ and $26.2 \%$ of the variation on the three axes respectively, with a final stress of 10.02 after 111 iterations (Fig. 4). Variation linked to differences in moisture levels was much higher for samples collected from the reconstructed soils than for those from the natural forest soil. Additionally, as moisture level increased, the soil microbial communities on the reclaimed sites became less similar to the natural soil microbial communities, as can be seen from increasing $\mathrm{T}$ values in individual MRPP tests (at $15 \%$ moisture, $T=-8.07 ; 30 \%$ moisture, $T=-11.31 ; 45 \%$ moisture, $T=-11.09$; and $60 \%$ moisture, $T=-12.22)$.

Site (including the three reclaimed sites and the natural forest stand), rather than moisture, was found to be the principal driving factor for the differences found between the reclaimed and natural soil microbial communities. Site was found to be the strongest grouping factor as it had a more negative $\mathrm{T}$ and a larger A value (T: -15.66; A: 0.12) than did moisture level (T: -6.76; A: 0.05). All sites and treatments (including the natural LFH) were found to be significantly different from one another. The reconstructed 
soil microbial communities were more different from those found in the natural forest (FFM vs. Natural LFH: T: -12.20; A: 0.11; PM vs. Natural LFH: T: -13.29; A: 0.11 ) than they were from each other (FFM vs. PM: T: -3.45; A: 0.18). However, both the FFM and PM soil microbial communities became less similar to the natural sites with increasing moisture.

\section{Discussion}

The combined influence of organic matter amendment and vegetation on soil microbial community

Based on plant cover (Fig. 1), we found that the use of FFM placed the vegetation community on a faster trajectory to ecosystem recovery. Differences in vegetation between the two reclamation treatments were linked to both total plant cover and species composition. Our results agreed with previous vegetation surveys completed on these sites, which noted significant differences in vegetation between the two treatments on all three sites. At Site 1, records from 1999 indicated plant cover to be higher for FFM than PM (Mapfumo 2003), although at the time plant cover was low (1-2\%), and much lower than what we measured during our study (10-30 \%). Further, on Site 3, an assessment completed in 2004 reported that plots reclaimed with FFM had significantly higher plant richness, diversity and total density than plots reclaimed with PM (Mackenzie and Naeth 2006).

Total microbial biomass on all reclaimed sites increased approximately $480 \%$ throughout our sevenyear monitoring period (Fig. 3), yet it failed to reach levels comparable to the natural reference stands. Total microbial biomass (total PLFAs) on the natural sites was comparable to the ranges reported in undisturbed aspen and mixedwood forest soils of western Canada, measured in central Alberta (Hannam et al. 2007) and the Athabasca Oil Sands Region (Dimitriu et al. 2010). While total soil microbial biomass was similar for the two reclamation treatments when calculated on a pergram of soil basis, results change when total biomass is calculated on a per-gram of soil carbon basis. Indeed, since the PM treatments contained approximately twice as much soil carbon as the FFM plots (Table 2), microbial biomass within the PM plots (per g of soil carbon) would be much lower than within the FFM plots. This indicates that organic matter composition, more so than its total amount, was affecting the microbial community within the reclaimed soils.

We found that the soil microbial community composition of the reclaimed sites remained statistically different from the natural stands throughout the sevenyear study. However, the soil microbial community composition on plots reclaimed with FFM became more similar to those found on the natural reference stands than the plots reclaimed with PM (Table 5). This followed the same pattern as vegetation (Fig. 1). Changes in microbial community composition have also been suggested to be related to changes in total microbial biomass (Bardgett et al. 1999; Lovell et al. 1995). Correspondingly, we found that as total microbial biomass increased, the soil microbial community composition of the reclaimed sites became more similar to that of the natural reference stands (Table 5), supporting this hypothesis. Moreover, a positive correlation between soil microbial biomass and plant cover has been reported as barren reclaimed sites become revegetated (DeGrood et al. 2005; Ponder and Tadros 2002). Similarly, in our study, the annual increase in microbial biomass (Fig. 3) followed increases in plant cover.

The differences between the FFM and PM treatments may not only be due to initial differences in the composition of the organic amendments, but may also be linked to differences in the plant communities growing on the two types of reconstructed soils (Fig. 1). This conclusion is drawn based on the increasing divergence with time between the soil microbial community composition found on the plots reclaimed with FFM and those reclaimed with PM (Table 4). Tree species and vegetative community composition have a significant impact on soil microbial community composition (Brockett et al., 2012; Grayston and Prescott, 2005) and different plants can host distinctive soil biota (Sylvain and Wall, 2011). As our experimental design does not allow for the separation of the combined effects of organic amendment and vegetation, we conclude that differences between plots is due to both the organic amendment as well as the vegetation communities becoming established on site. This deduction is further supported by research that has established the influence of vegetation to be most strongly expressed in the soil layer formed by new or fresh litter inputs (Leckie et al. 2004), similar to that which we measured. 
Fig. 3 Total topsoil microbial biomass sampled a nnually in August (20042010) on three reclaimed sites and three natural sites (displayed together) in the Athabasca Oil Sands Region

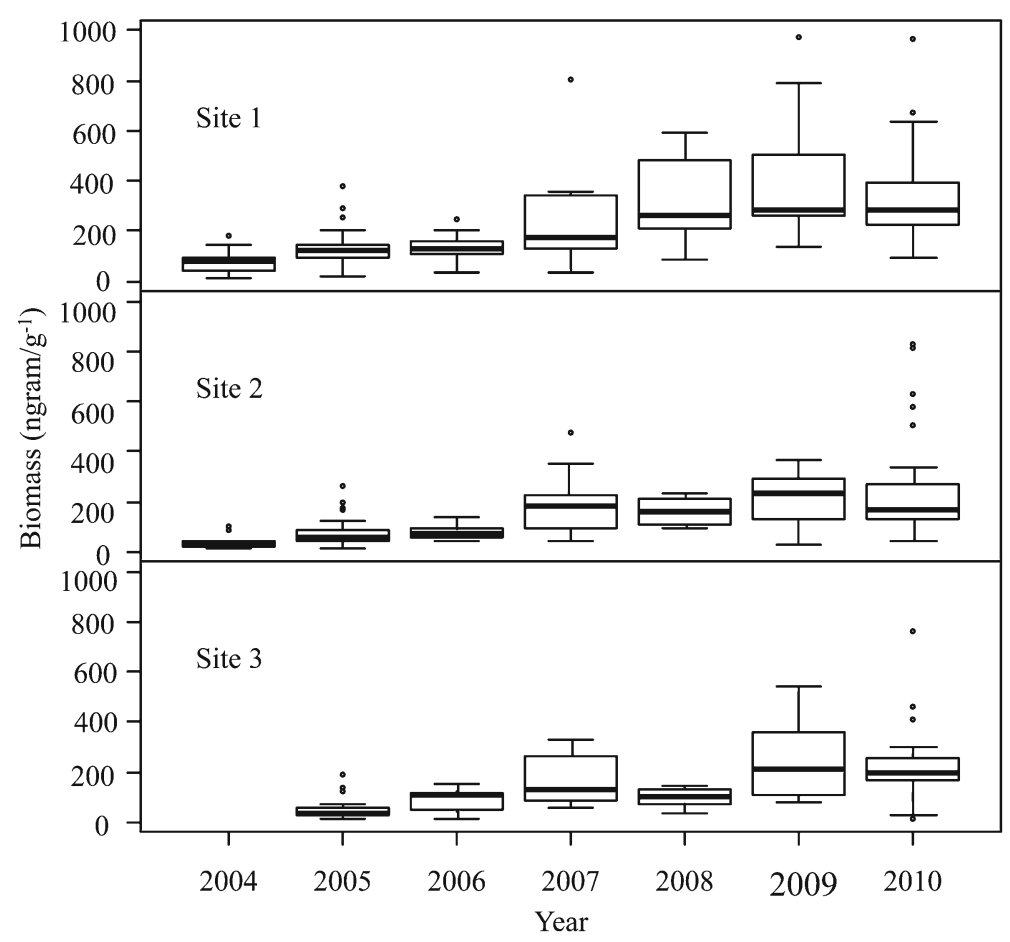

Soil microbial community response to moisture

As previously reported by McMillan et al. (2007), soil gravimetric water content was lower on all reclaimed plots than on the natural reference stands (Table 2). We hypothesized that because gravimetric soil moisture in the reconstructed soils $(8-17 \%)$ was significantly lower than that of the undisturbed soils $(60 \%)$, by increasing moisture, and hence lifting this potential limitation, the microbial communities on the reclaimed sites would become more similar to those found on the references stands. Our results, however, showed a completely opposite trend, since we found that increasing soil moisture in the laboratory experiment increased the difference between reclaimed and natural soil microbial community composition (Fig. 4). Previous work has found increased moisture to increase microbial respiration and microbial biomass nitrogen in soils reclaimed with both FFM and PM (McMillan 2007). The authors found that soils reclaimed with FFM had higher respiration rates and microbial biomass $\mathrm{N}$ than those reclaimed with PM; though, neither the rate of respiration or microbial biomass $\mathrm{N}$ in either reconstructed soil ever reached the levels observed in the natural reference soil (kept at its original in situ moisture content) (McMillan 2007). Here we conclude that differences in the soil microbial composition between the reclaimed sites and the natural forest stands were not solely due to a moisture limitation, but rather to more complex and indirect soil-plant interactions. This conclusion is further supported by the lack of correlation found between sampling date (year), the grouping factor found to have the greatest influence on soil microbial community composition of reclaimed sites (Fig. 2), and either annual or August precipitation.

As well, our results suggest that the natural forest soil microbial communities we sampled may be more robust to environmental change than reclaimed soils in the AOSR. When the soil microbial communities of both the reconstructed and natural soils were assessed together, the natural soil (from the aspen-dominated natural forest stand) appeared more resistant to changes in moisture content than the reconstructed soils (Fig. 4). Many studies have concluded that natural soil microbial communities are sensitive to fluctuation in environmental conditions (Bardgett et al. 1999; Swallow et al. 2009; Wilkinson et al. 2002); however, this conclusion has been based mainly on observational differences in the soil microbial communities linked to different sampling dates. Soil microbial community resistance to changes in soil moisture is thought to be determined by the inherent characteristics of the microorganisms present (Vangestal et al. 1993). Jangid et al. (2011) identified land use history 


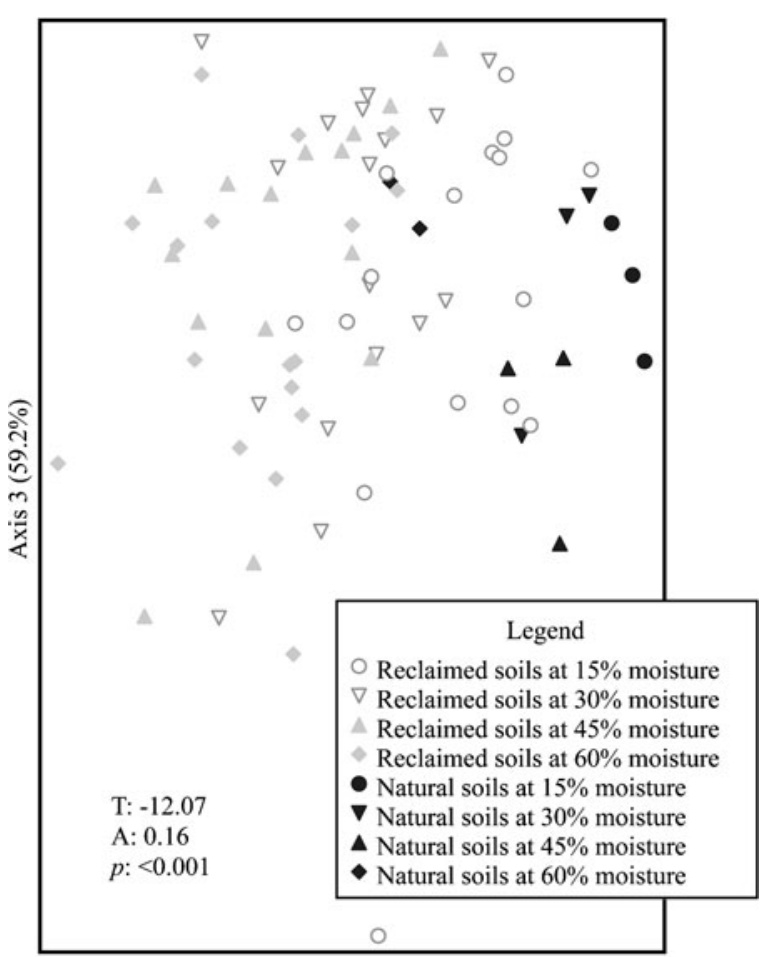

Axis $2(22.6 \%)$

Fig. 4 NMDS ordination of topsoil PLFA profiles from natural and reclaimed sites in the Athabasca Oil Sands Region, which were incubated for 6 months at four gravimetric moisture contents $(15 \%, 30 \%, 45 \%$ and $60 \%)$. The $\mathrm{T}$ value represents the difference(s) between groups, a more negative value signifying a greater difference; the A value represents the variation within groups, where 1 signifies that all points within the group are identical and 0 indicates a variation equal to that of random numbers; and the $p$ value represents the significance of these values (Zimmerman et al. 1985)

as having a stronger influence on soil microbial communities than vegetation or soil properties. Thus, reclamation or site history may be the reason the reconstructed soils, both FFM and PM (after 6-12 years since reclamation) responded similarly to one another but differently from the natural site. Furthermore, the variation in response to moisture observed between the reconstructed and natural soils is a clear indicator that the soil microbial communities in the reclaimed plots differ from or are not yet functioning as those in the natural stands.

Importance of native organic matter and vegetation for reconstructing soils

The use of FFM as a soil organic amendment has been shown to be advantageous in terms of native upland forest vegetation establishment and survival when reclaiming sites in northeastern Alberta (AMEC Earth and Environmental 2006; Brown et al. 2003; Mackenzie and Naeth 2006; Mapfumo 2003). Here we found that the use of FFM also promoted the development of soil microbial communities more similar to those found on natural forest stands than did the use of organic materials salvaged from surrounding peatlands. Similarly, within each site, the vegetation on the plot reclaimed with FFM was more similar to the vegetation on the plot reclaimed with PM. Thus, the accelerated development of the "natural", or target, soil microbial communities we observed on the plots reclaimed with FFM, may be linked to the similarities in plant communities found between these plots and the natural forest reference stand.

The exact timeline required for full microbial recovery following soil reconstruction is difficult to predict and depends both on environmental conditions and on the reclaimed target ecosystem. For instance, following surface coal mining in the semiarid region of Wyoming, microbial biomass carbon in soils reclaimed to grasslands recovered to predisturbance levels after 11-26 years (Anderson et al. 2008). However, several other studies both within (Mummey et al. 2002a, 2002b) and outside the aforementioned region Donn (Banning et al. 2011; Dimitriu et al. 2010; Insam and Domsch 1988) have reported that soil microbial community composition and biomass of reclaimed soils remained different from pre-disturbance conditions even after 20 years since reclamation. Further, the investigation of artic soils has revealed that the structure and function of soil microbial communities did not vary despite long-term environmental changes such as increased temperature and increased nutrient availability (Lamb et al., 2011). Alternatively, it has been suggested that reclaimed sites might develop into unique or "novel" ecosystems wherein elements from the target or reference ecosystem are integrated with components from the newly established or reclaimed landscape (Hobbs et al., 2009). Reclaimed sites in this study appear to be on a trajectory towards ecosystem recovery in terms of soil microbial biomass. However, six (Site 3), 10 (Site 2) and 12 (Site 1) years after reclamation the reconstructed soils only support, on average, $20 \%$ of the total microbial biomass found in the natural reference soils. This establishes that the time needed to reach ecosystem recovery at these sites will extend well beyond a 
decade, or alternatively, suggests that soil microbial composition may never return to pre-disturbance composition.

Acknowledgments Funding for this research was provided by the Canadian Oilsands Network for Research and DevelopmentEnvironmental and Reclamation Research Group (CONRADERRG) as well as by a Natural Science and Engineering Research Council (NSERC) CRD grant to S. Quideau. We would like to express gratitude to our field and laboratory assistants, P. Sorensen, M. Swallow and N. Baker and extend a special thank you to both C. E. Norris and A. Macintosh for their endless support and assistance throughout the project. We are also grateful to J. Lloyd for her help with laboratory methods and equipment. Travel for this project was funded, in part, by the Northern Scientific Training Program of Indian and Northern Affairs, Canada and a Circumpolar/Boreal Alberta Research grant to A.S. Hahn.

Open Access This article is distributed under the terms of the Creative Commons Attribution License which permits any use, distribution, and reproduction in any medium, provided the original author(s) and the source are credited.

\section{References}

AMEC Earth and Environmental (2003) Vegetation and soil characteristics in reclaimed areas Annual Report. Steepbank north dump capping study. Suncor Energy Inc.

AMEC Earth and Environmental (2006) Vegetation and soil characteristics in reclaimed areas on Suncor lease: 2005 Annual Report. Suncor Energy Inc.

Anderson JD, Ingram LJ, Stahl PD (2008) Influence of reclamation management practices on microbial biomass carbon and soil organic carbon accumulation in semiarid mined lands of Wyoming. Appl Soil Ecol 40:387-397

Bach L, Frostegard A, Ohlson M (2008) Variation in soil microbial communities across a boreal spruce forest landscape. Can J Forest Res 38:1504-1516

Banning NC, Gleeson DB, Grigg AH, Grant CD, Andersen GL, Brodie EL, Murphy DV (2011) Soil microbial community successional patterns during forest ecosystem restoration. Appl Environ Microbiol 77:6158-6164

Bardgett RD, Lovell RD, Hobbs PJ, Jarvis SC (1999) Seasonal changes in soil microbial communities along a fertility gradient of temperate grasslands. Soil Biol Biochem 31:1021-1030

Bell CW, McIntyre N, Cox S, Tissue D, Zak J (2008) Soil microbial responses to temporal variations of moisture and temperature in a Chihuahuan Desert Grassland. Micro Ecol 56:153-167

Bell CW, Acosta-Martinez V, McIntyre NE, Cox S, Tissue DT, Zak JC (2009) Linking microbial community structure and function to seasonal differences in soil moisture and temperature in a Chihuahuan desert grassland. Microb Ecol $58: 827-842$

Bradshaw AD (1984) Ecological principles and land reclamation practice. Landsc Plan 11:35-48
Brockett FT, Prescott CE, Grayston SJ (2012) Soil moisture is the major factor influencing microbial community structure and enzyme activities across seven biogeoclimatic zones in western Canada. Soil Biol Biochem 44:9-20

Broughton LC, Gross KL (2000) Patterns of diversity in plant and soil microbial communities along a productivity gradient in a Michigan old-field. Oecologia 125:420-427

Brown JT, Pollard JS, Leskiw LA (2003) LFH and shallow mineral horizons as inoculants on reclaimed areas to improve native species catch. 2003 Status Report. Paragon Soil and Environmental Consulting Inc, Edmonton

DeGrood S, Claassen V, Scow K (2005) Microbial community composition on native and drastically disturbed serpentine soils. Soil Biol Biochem 37:1427-1435

Dimitriu PA, Prescott C, Quideau SA, Grayston SJ (2010) Impact of reclamation of surface-mined boreal forest soils on microbial community composition and function. Soil Biol Biochem 42:2289-2297

Environment Canada (2010) National Climate Data and Information Archive, for Fort McMurray, AB. Availble at http:// www.climate.weatheroffice.gc.ca/climateData/canada_e.html (verified 17 October 2011).

Fierer N, Schimel J, Holden P (2003) Influence of dryingrewetting frequency on soil bacterial community structure. Microb Ecol 45:63-71

Flanagan PW, Vancleve K (1983) Nutrient cycling in relation to decomposition and organic-matter quality in Taiga ecosystems. Can J Forest Res 13:795-817

Frostegard A, Baath E (1996) The use of phospholipid fatty acid analysis to estimate bacterial and fungal biomass in soil. Biol Fertil Soils 22:59-65

Frouz J, Elhottova D, Pizl V, Tajovsky K, Sourkova M, Picek T, Maly S (2007) The effect of litter quality and soil faunal composition on organic matter dynamics in post-mining soil: A laboratory study. Appl Soil Ecol 37:72-80

Fung MYP, Macyk TM (2000) Reclamation of oil sands mining areas. In Reclamation of Drastically Disturbed Lands. Eds. R I Barnhisel, R G Darmody and W L Daniels. pp 755774. American Society of Agronomy

Fyles JW, McGill WB (1987) Nitrogen mineralization in forest soil profiles from central Alberta. Can J Forest Res 17:242.249

Grayston SJ, Prescott CE (2005) Microbial communities in forest floors under four tree species in coastal British Columbia. Soil Biol Biochem 37:1157-1167

Hannam KD, Quideau SA, Kishchuk BE (2006) Forest floor microbial communities in relation to stand composition and timber harvesting in northern Alberta. Soil Biol Biochem 38:2565-2575

Hannam KD, Quideau SA, Kishchuk BE (2007) The microbial communities of aspen and spruce forest floors are resistant to changes in litter inputs and microclimate. Appl Soil Ecol 35:635-647

Hobbs RJ, Higgs E, Harris JA (2009) Novel ecosystems: implications for conservation and restoration. Trends Ecol Evol 24:599-605

Insam H, Domsch KH (1988) Relationship between soil organic-carbon and microbial biomass on chronosequences of reclamation sites. Microb Ecol 15:177-188

ISO 11465 (1993) Soil quality determination of dry matter and water content on a mass basis. Gravimetric method. 
International organization for standardization. Geneva, Switzerland.3p (available at www.iso.ch).

Jangid K, Williams MA, Franzluebbers AJ, Schmidt TM, Coleman DC, Whitman WB (2011) Land-use history has a stronger impact on soil microbial community composition than aboveground vegetation and soil properties. Soil Biol Biochem 43:2184-2193

Kalra YP, Maynard DG (1991) Methods manual for forest soil and plant analysis. Forestry Canada northwest region northern forestry center. Rep. NOR-X-319. Forestry Canada, Northwest Region, Northern Forestry Center, Edmonton, AB Canada.

Lamb EG, Sukkyun H, Lanoil BD, Henery GHR, Brummells ME, Banerjees S, Siciliano SD (2011) A high artic soil ecosystem resists long-term environmental manipulations. Glob Chang Biol 17:3187-3194

Lanoue A (2003) Phosphorus content and accumulation of carbon and nitrogen in boreal forest soils. University of Alberta, Edmonton

Leckie SE, Prescott CE, Grayston SJ, Neufield JD, Mohn WW (2004) Characterization of humus microbial communities in adjacent forest types that differ in nitrogen availability. Microbial Ecology 48:29-40

Legendre P, Gallagher E (2001) Ecologically meaningful transformations for ordination of species data. Oecologia 129:271-280

Lindo Z, Visser S (2003) Microbial biomass, nitrogen and phosphorus mineralization, and mesofauna in boreal conifer and deciduous forest floors following partial and clearcut harvesting. Can J Forest Res 33:1610-1620

Lovell RD, Jarvis SC, Bardgett RD (1995) Soil microbial biomass and activity in long-term grasslands- Effects of management changes. Soil Biol Biochem 27:969-975

Mackenzie D, Naeth A (2006) Assisted natural recovery using a forest soil propagule bank in the Athabasca Oil Sands Region. In Seeds: Biology, Development and Ecology. Eds. S Navie, S Adkins and S Ashmore. pp 374-382. CAB International Publishing.

Mapfumo E (2003) Analysis of LFH Data Report. Department of Renewable Resources, University of Alberta, Edmonton, AB Canada.

McMillan R, Quideau S, MacKenzie M, Biryukova O (2007) Nitrogen mineralization and microbial activity in oil sands reclaimed boreal forest soils. J Environ Qual 36:14701478

Mummey D, Stahl P, Buyer J (2002a) Microbial biomarkers as an indicator of ecosystem recovery following surface mine reclamation. Appl Soil Ecol 21:251-259

Mummey D, Stahl P, Buyer J (2002b) Soil microbiological properties 20 years after surface mine reclamation: spatial analysis of reclaimed and undisturbed sites. Soil Biol Biochem 34:1717-1725

Natural Regions Committee (2006) Natural Regions and Subregions of Alberta. Compiled by D.J Downing and W.W. Pettapiece. Government of Alberta. Publication No. T/852.

Pare D, Bergeron Y, Camire C (1993) Changes in the forest floor of Canadian southern boreal forest after disturbance. $\mathrm{J}$ Veg Sci 4:811-818

Ponder F, Tadros M (2002) Phospholipid fatty acids in forest soil four years after organic matter removal and soil compaction. Appl Soil Ecol 19:173-182
Prévost-Bouré NC, Ranjard L, Maron PA, Nowak V, Dufrene E, Damesin C, Soudani K, Lata JC (2011) Seasonal dynamics of the bacterial community in forest soils under different quantities of leaf litter. Appl Soil Ecol 47:14-23

Priha O, Grayston SJ, Hiukka R, Pennanen T, Smolander A (2001) Microbial community structure and characteristics of the organic matter in soils under Pinus sylvestris, Picea abies and Betula pendula at two forest sites. Biol Fertil Soils 33:17-24

Saetre P, Baath E (2000) Spatial variation and patterns of soil microbial community structure in a mixed spruce-birch stand. Soil Biol Biochem 32:909-917

Schutter M, Dick R (2001) Shifts in substrate utilization potential and structure of soil microbial communities in response to carbon substrates. Soil Biol Biochem 33:1481-1491

Shledrick BH, Wang C (1993) Particle size analysis (Hydrometer) Agriculture Canada Ottawa, Ontario. CSSS, Lewis Publishers, Canada

Soil Classification Working Group (1998) The Canadian System of Soil Classification. 3rd ed. Agriculture Canada Publ., Ottawa, ON.

Swallow M, Quideau S, MacKenzie M, Kishchuk B (2009) Microbial community structure and function: The effect of silvicultural burning and topographic variability in northern Alberta. Soil Biol Biochem 41:770-777

Sylvain ZA, Wall DH (2011) Linking soil biodiversity and vegetation: implications for a changing planet. Am J Bot 98:517-527

Turchenek LW, Lindsay JD (1982) Soils inventory of the Alberta oil sands environmental research program study area. In Alberta Research Council Report 122.

Vancleve K, Yarie J, Erickson R, Dyrness CT (1993) Nitrogen mineralization and nitrification in successional ecosystems on the Tanana river floodplain, interior Alaska. Can J Forest Res 23:970-978

Vangestal M, Merckx R, Vlassak K (1993) Microbial biomass responses to soil drying and rewetting-the fate of fastgrowing and slow-growing microorganisms in soils from different climates. Soil Biol Biochem 25:109-123

Wagner G (1998) Principles and Applications of Soil Microbiology. In: Sylvia DM, Fuhrmann JJ, Hartel PG, Zuberer DA (eds) Principles and applications of soil microbiology. Prentice Hall, Upper Saddle River, pp 218-258

Whittle CA, Duchesne LC, Needham T (1997) The importance of buried seed and vegetative propagation in the development of post fire communities. Environmental Review 5:79-87

Wilkinson S, Anderson J, Scardelis S, Tisiafouli M, Taylor A, Wolters V (2002) PLFA profiles of microbial communities in decomposing conifer litters subject to moisture stress. Soil Biol Biochem 34:189-200

Zak DR, Holmes WE, MacDonald NW, Pregitzer KS (1999) Soil temperature, matric potential, and the kinetics of microbial respiration and nitrogen mineralization. Soil Sci Soc Am J 63:575-584

Zimmerman GM, Goetz H, Mielke PW (1985) Use of improved statistical-method for group comparisons to study effects of prairie fire. Ecology 66:606-611

Zogg GP, Zak DR, Ringelberg DB, MacDonald NW, Pregitzer KS, White DC (1997) Compositional and functional shifts in microbial communities due to soil warming. Soil Sci Soc Am J 61:475-481 